\title{
THE GEOECONOMIC CHALLENGE TO INTERNATIONAL ECONOMIC LAW: LESSONS FROM THE REGULATION OF DATA IN CHINA
}

\begin{abstract}
Henrique Choer Moraes ${ }^{1}$
A clash of economic models with the potential to disrupt international economic law is emerging in the wake of China's increasing global presence. At the center of this clash of models is the claim that China introduces a 'geoeconomic' element to economic relations, while others follow a 'market-orientation'. The emergence of such clash of models owes significantly to the fact that China has proven unwilling to change course to meet expectations of other actors. In an attempt to manage China's competition, actors such as the US are themselves resorting to geoeconomic measures, thereby triggering a 'geoeconomic chain reaction'. The article argues that such geoeconomic dynamic changes the logic underlying global economic relations, with implications for international economic law. The article examines the regulation of data in China, particularly data localization provisions, to show (i) how this legislation advances the geoeconomic goal of helping China to become a leader in artificial intelligence; and (ii) the consequences of China's approach to data regulation over the prospects of international rules being agreed in this area-so as to project the impact of geoeconomics on international economic law.
\end{abstract}

\section{INTRODUCTION}

It is difficult to deny that international economic law is undergoing an 'existential crisis'. ${ }^{2}$ The most visible institutional challenges accounting for the current soul-searching stem from the US invocations of national security as a justification for trade restrictive measures on steel and aluminum ${ }^{3}$ as well as the US resistance to unlock the appointment of WTO's Appellate Body (AB) members. ${ }^{4}$ These developments endanger international economic law to a level that cannot be overstated, ${ }^{5}$ not least because it opposes the US to virtually all other economies. ${ }^{6}$

But a more fundamental shift is beginning to materialize, portending a structural disruption of international economic law: the perception that the Chinese state-centric model is irreconcilable with the key pillars of trade, investment and financial rules in force for the past decades. A clash of economic models seems to be coming to a head in the wake of China's increasingly global economic presence.

The clash of models was laid bare at the WTO General Council meeting of July 2018, when the US Permanent Representative charged that 'China has not been moving toward a fuller embrace

\footnotetext{
${ }^{1} \mathrm{PhD}$ candidate, Leuven Centre for Global Governance Studies (KU Leuven). Diplomat, Ministry of Foreign Affairs, Brazil. The views and opinions expressed in this article are the sole responsibility of the author and do not necessarily reflect the positions of the Brazilian government.

${ }^{2}$ World Trade Organization, 'China's proposal on WTO reform', Communication from China, document WT/GC/W/773, 13 May 2019.

${ }^{3}$ White House, 'President Trump Approves Section 232 Tariff Modifications', Press release of March 22, 2018. See Kathleen Claussen, 'Old Wine in New Bottles? The Trade Rule of Law', 44 The Yale Journal of International Law Online (2019), pp. 61; Tania Voon, 'The security exception in WTO law: entering a new era', 113 AJIL Unbound (2019), p. 45

${ }^{4}$ See Gregory Schaffer, 'A tragedy in the making? The decline of law and the return of power in international trade relations', 44 The Yale Journal of International Law Online (2018), pp. 37; Rachel Brewster, 'WTO dispute settlement: can we go back again?', 113 AJIL Unbound (2019), p. 61.

${ }^{5}$ Geraldo Vidigal, 'Westphalia Strikes Back: The 2018 Trade Wars and the Threat to the WTO Regime', Amsterdam Law School Research Paper No. 2018-31, available at https://ssrn.com/abstract=3259127.

${ }^{6}$ There are, of course, other challenges to international economic regulation, chiefly emerging from the antiglobalization sentiment currently spreading across the developed world, which is a topic not addressed in this article.
} 
of market-based policies and practices since it joined the WTO in 2001'. ${ }^{7}$ China's Ambassador reacted stating that ' $[\mathrm{t}]$ here are more than one model of market economy in this world. China has been vigorously exploring a road of market economy which suits China's own national situation and circumstances, and we have made remarkable progress in this endeavor. Whatever others may say, we will march along this road unswervingly'. ${ }^{8}$ As this exchange reveals, the standoff involves more than ascertaining whether specific rules are being observed or not; instead, it is about defining whether the WTO regime can accommodate different 'models of market economy'.

What makes this perceived clash between models even more significant for international economic law is that this is not an exclusive US agenda or concern - as are the problems mentioned above regarding the WTO AB and the measures imposed on steel and aluminum. Other major players also share this view. For instance, since May 2018 at least, the trade ministers of US, the EU and Japan have been actively collaborating on an agenda that seeks to address problems posed by 'non-market-oriented policies of third countries'. 9

At the center of the clash of models challenging international economic law lies the claim that China introduces a 'geoeconomic' element to economic relations, while other actors constrain their economic actions to the 'market-orientation' underpinning the existing rules of the road. The notion of 'geoeconomics' implies the use of economic measures 'to promote and defend national interests, and to produce beneficial geopolitical results', ${ }^{10}$ subjecting efficiency considerations and a market-driven logic to the pursuit of security and strategic goals. Thanks to its state-centric model, China is often considered as 'the world's leading practitioner of geoeconomics', ${ }^{11}$ an actor that 'plays globalization by different rules'. ${ }^{12}$

Irrespective of whether the anxieties elicited by China are justified or not, many economiesled by the US and gradually including also the EU-are beginning to respond to China's growing role as a global trader and investor by also deploying geoeconomic measures. Thus, the clash of models is gradually ushering in a geoeconomic chain reaction.

China's rise has made salient the strategic value of a number of sectors or assets which until now have been by and large left to the free interplay of global market forces. Now, in areas such as the technology sector, governments in the US, Europe and elsewhere are stepping in using economic measures not necessarily to pursue efficiency gains (in fact, some measures run against corporate interests), but predominantly to defend strategic objectives such as retaining the leadership in or self-reliance on certain technologies. A number of geoeconomic measures is being adopted or discussed in the US and elsewhere with a view to advancing the (ever-

\footnotetext{
${ }^{7}$ Statement delivered by Ambassador Dennis Shea, 'Views on China's trade-disruptive economic model and implications for the WTO', WTO General Council, Geneva, 26 July, 2018, https://geneva.usmission.gov/2018/07/27/55299/

${ }^{8}$ Statement by H.E. Ambassador Dr. Zhang Xiangchen at the WTO General Council Meeting, Geneva, 26 July, 2018, http://wto2.mofcom.gov.cn/article/chinaviewpoins/201807/20180702770676.shtml

${ }^{9}$ Joint Statement on Trilateral Meeting of the Trade Ministers of the United States, Japan, and the European Union, Paris, May 31, 2018, https://ustr.gov/about-us/policy-offices/press-office/press-releases/2018/may/jointstatement-trilateral-meeting.

${ }^{10}$ Robert D. Blackwill and Jennifer M. Harris, War by Other Means: Geoeconomics and Statecraft (Cambridge, MA: Harvard University Press, 2016), p. 9; Anthea Roberts, Henrique Choer Moraes and Victor Ferguson, 'The geoeconomic world order', Lawfare, 19 November 2018.

${ }^{11}$ Blackwill and Harris, note 10, p. 93.

${ }^{12}$ Dani Rodrik, 'The WTO has become dysfunctional', Financial Times, August 5, 2018.
} 
expanding) ${ }^{13}$ goal of 'national security' (e.g., investment screening legislations) or broader strategic interests (e.g. the promotion of 'European champions').

International economic law as we know it for the past decades is driven by such goals as curbing economic nationalism, harnessing the positive aspects of interdependence and increasing the rule of law in economic relations. These objectives are at risk by this chain reaction in which major economies make geoeconomics the logic driving their economic relations. How does the increasing resort to geoeconomic measures impact the functioning of international economic law? This article addresses this question by looking at the regulation of data in China.

Unlike the approaches adopted by the US and the EU, China imposes a number of wide-ranging restrictions on cross-border data flows. ${ }^{14}$ It also requires most data generated in China to be stored in servers located in its territory. Both measures are expressions of the Chinese view of 'Internet sovereignty', ${ }^{15}$ an approach that stands apart from the goal of a free Internet, raising significant implications for trade rules, not least because they are justified by national security. Still, as argued in this article, for all the concerns about protecting 'data security', ${ }^{16}$ data localization and restrictions on cross-border data flows also play a key role advancing China's leadership in the development of artificial intelligence (AI). In so doing, the regulation of data is also part of China's geoeconomic toolkit.

This article examines the regulation of data in China as a case that helps making sense of how geoeconomics plays out, in particular how it blurs the lines dividing economic interests from security concerns. It also provides rich insights into how the clash of models expresses itself concretely, given the entrenched positions setting apart actors in this area. This dynamic in turn produces systemic effects on how this field is regulated, thus suggesting elements to reflect upon the evolution of international economic law in this and in other issue-areas.

Following this introduction, Part I sets the context, marked by an increasingly open clash of models and a gradually expanding geoeconomic chain reaction across different regulatory areas. Part II looks at the case of data localization and of restrictions to cross-border data flows in China with a view to unpack what geoeconomics implies in practice. Since the regulation of data in China is an expression of the clash of models slowly emerging at the WTO as well as in other international settings, Part III focuses on how the competing approaches to this issue-area are gradually reshaping international economic law in areas such as electronic commerce. The final section summarizes the implications of a turn to geoeconomics to international economic law going forward.

\footnotetext{
13 J. Benton Heath, 'The New National Security Challenge to the Economic Order', Yale Law Journal, forthcoming (2019). Available at SSRN: https://ssrn.com/abstract=3361107

${ }^{14}$ Susan Ariel Aaronson and Patrick Leblond, 'Another digital divide: The rise of data realms and its implications for the WTO’, 21 Journal of International Economic Law (2018), 245-272.

${ }^{15}$ Sarah McKune and Shazeda Ahmed, 'The Contestation and Shaping of Cyber Norms Through China's Internet Sovereignty Agenda', International Journal of Communication 12(2018), available at http://ijoc.org; Laura DeNardis, Gordon Goldstein, and David A. Gross, 'The Rising Geopolitics of Internet Governance: Cyber Sovereignty v. Distributed Governance’, Columbia School of International \& Public Affairs, November 2016, available at https://sipa.columbia.edu/sites/default/files/The\%20Rising\%20Geopolitics_2016.pdf; Geoffrey Hoffman, 'A clash of cyber civilizations', China File, February 15, 2018, available at http://www.chinafile.com/reporting-opinion/viewpoint/clash-of-cyber-civilizations.

${ }^{16}$ China's proposal on WTO reform, note 2 above, paragraph 2.22 .
} 


\section{GEOECONOMICS AND THE CHANGING DYNAMIC OF INTERNATIONAL ECONOMIC LAW}

In what possibly amounts to one of the most consequential shifts in global politics, the US recently decided to change its policy to China. The 2017 National Security Strategy emphasizes the need to 'rethink the policies of the past two decades - policies based on the assumption that engagement with rivals and their inclusion in international institutions and global commerce would turn them into benign actors and trustworthy partners'. ${ }^{17}$

This represents a marked departure from the previous US policy to China, in which it was expected (in the US but also in Europe) that China could be induced to move towards a marketoriented economic model if it were admitted to global regimes disciplined by international economic law (the 'socialization' approach). Following more than four decades of mixed success, it became difficult to maintain this approach in the face of unaddressed complaints against China over the years, coupled with the realization that Beijing was playing geoeconomics as it grew richer and powerful, instead of moving towards becoming a marketoriented economy (the 'reckoning' moment). ${ }^{18}$

This process evolved to the current stage in which 'the raw, strategic fundamentals of the [U.S.China] relationship are now being laid bare'. ${ }^{19}$ The stance that gains currency today is the open recognition that there is an irreconcilable 'clash of models' whereby the US, followed by other key actors, is confronted with the increasing inability to force a powerful China to cave in to American demands. Since this tension can hardly be solved within the near future, what is left is to try to manage it - and one way to do so is by deploying geoeconomic measures against Chinese interests (triggering the 'geoeconomic chain reaction').

Such changing context is transforming economic relations at the global level. By introducing a geoeconomic logic, a powerful China is forcing other actors to do the same, for fear that openness to economic interdependence might be taken advantage of as some sort of naïveté. ${ }^{20}$ It is a new game and this part of the article looks at how we got here.

\section{Tracing the (re)emergence of geoeconomics in economic relations}

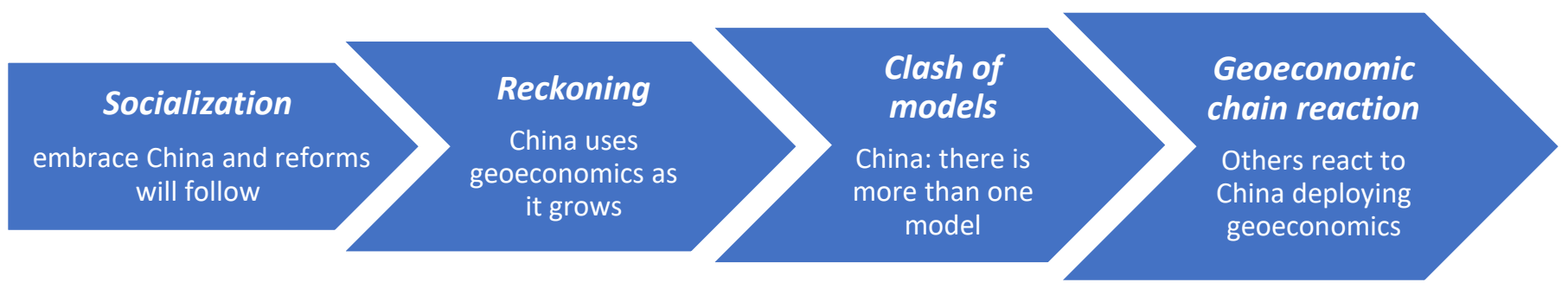

\footnotetext{
${ }^{17}$ National Security Strategy of the United States of America, December 2017, p. 3.

${ }^{18}$ Kurt M. Campbell and Ely Ratner, 'The China reckoning - How Beijing defied American expectations', 97 Foreign Affairs 2 (2018).

${ }^{19}$ Kevin Rudd, 'The avoidable war - Reflections on U.S.-China relations and the end of strategic engagement', Asia Society Policy Institute, January 2019, p. 40.

${ }^{20}$ Jean-Claude Juncker, State of the Union 2018 - The Hour of European Sovereignty, p. 3, available at https://ec.europa.eu/commission/sites/beta-political/files/soteu2018-speech_en_0.pdf.
} 


\section{A. The (re)emergence of geoeconomics changes the game}

A key criticism defining the current 'clash of models' is that China operates by 'geoeconomic' means, thereby violating the rules of the road, if not literally at least in spirit.

Geoeconomics is a term coined by Edward Luttwak to describe 'the admixture of the logic of conflict with the methods of commerce' in which 'states are inherently inclined to strive for relative advantage against like entities on the international scene, even if only by means other than force'. ${ }^{21}$ This is a vision that introduces a zero-sum quality to international economic relations; in this sense it incorporates a different rationale than that which inspired international economic law.

While there is no agreed definition for 'geoeconomics', a number of elements are commonly recognized across the literature. The state-centered, realist nature of the concept ${ }^{22}$ is one of these elements. A corollary of the state-centered nature of geoeconomics is that 'profit' is not the main goal to be pursued. As The Economist recently put it, describing the state of the USChina rivalry, '[s]uddenly, (...) making money is not enough'. ${ }^{23}$ For this reason it is sometimes difficult to simply dismiss geoeconomic policies as protectionism. Present is also a component of non-economic considerations, often expressed in an expanding notion of 'national security'.

This is an environment more hostile to market actors seeking to operate globally, or at least a more costly one. As elaborated below, international economic law risks becoming more politicized (and less legalized), with implications for the precision, predictability and enforcement of rules applicable to trade, investment and finance. As Blackwill and Harris note, ' $[\mathrm{w}]$ here business dealings occur on terms that go well beyond purely market means or profit logic, it imposes a class of international commerce fundamentally out of reach for private firms'. ${ }^{24}$

To be sure, geoeconomics is not a new development. It can be reasonably argued that, to some extent, most actors have resorted in one or another to geoeconomic measures. It can also be persuasively claimed that economic relations have always been about pursuing national strategic interests, even as these relations were spearheaded by market actors. But international economic law rules certainly established limits to such action.

If anything, though, China's economic presence introduces a challenge of scale to this picture of relative stability. It is unclear whether international economic law is capable of absorbing 'the implications if a $\$ 13$ trillion China decides to revert to non-market solutions to managing its economy. ${ }^{25}$ Because of its uniqueness, China's impressive global reach, not only as the

\footnotetext{
${ }^{21}$ Edward Luttwak, 'From geopolitics to geo-economics: logic of conflict, grammar of commerce', in Gearóid Ó Tuathail et al (eds.), The geopolitics reader (London: Routledge), 2003, p. 126.

${ }^{22}$ Sören Scholvin and Mikael Wigell, 'Geo-economics as concept and practice in international relations', Finnish Institute of International Affairs Working Paper 102, April 2018, p. 6.

${ }^{23}$ The Economist, 'Trade can no longer anchor America's relationship with China', May 16, 2019.

${ }^{24}$ Blackwill and Harris, note 10 above, p. 42.

${ }^{25}$ Daniel Rosen, 'Is China's system a concern for the US economy and manufacturing?', Testimony before the US Senate Committee on Commerce, Science and Transportation Subcommittee on Security, March 7, 2019, p. 2 .
} 
world's main exporter since $2013^{26}$ but also as one of the main suppliers of foreign investment, ${ }^{27}$ is testing the main tenets of international economic law.

\section{B. The entrenchment of the clash of models and the rise of the geoeconomic chain reaction}

The perception that we are witnessing a clash of economic models is premised, firstly, on the fact that more countries are increasingly outspoken about their criticisms regarding China's command of its economy, while these criticisms were more muted previously. But the idea that there is a 'clash' owes significantly to the fact that China has proven not malleable and, in fact, unwilling to change course to meet expectations of other actors.

By means of its deep-pocketed and ubiquitous state, China is accused of leveraging its economic power for strategic uses. China's actions as a global investor-whether directly by the state or indirectly by state-owned enterprises (SOEs) and private actors - are increasingly treated in other countries as tools in the pursuit of strategic goals. Accordingly, in the view of the US government, by means of 'state-subsidized takeovers' ${ }^{28}$, not driven by 'market-based considerations" ${ }^{29}$, 'China directs and supports its firms to seek technologies that enhance China's development goals in each strategic sector' ${ }^{30}$. Efficiency gains hardly justify a number of these investment decisions, since 'many of the Chinese firms that engage in overseas acquisitions in manufacturing do not appear to possess the firm-specific ownership advantages normally associated with acquiring firms' ${ }^{31}$. These firms, moreover, benefit from 'financial support not available in the private market'. ${ }^{32}$ Albeit with a marked difference in tone, Europe seems to be heading in a similar direction, recognizing that 'the balance of challenges and opportunities presented by China has shifted'. ${ }^{33}$

The divergence of views over the nature of international economic law has certainly become more salient. What is more alarming, though, is that it is also increasingly entrenched. Thus, China retorts to these complaints by taking issue with '[s]ome members [that] do not accept the diversity of development models' and that 'point fingers to other members' legitimate developmental models and policy measures, such as state-owned-enterprises and industrial subsidies'. ${ }^{34}$ China's position on WTO reform includes a number of specific proposals that challenge views traditionally held by the US and the EU. They include increasing the flexibility for granting subsidies, ${ }^{35}$ all the while contesting the discrimination 'against SOEs in foreign

\footnotetext{
${ }^{26}$ World Trade Organization, International Trade Statistics 2014, p.15.

${ }^{27}$ China ranked third in FDI outflows in 2018. See UNCTAD, World Investment Report 2018 - Investment and new industrial policies, p. 6.

${ }^{28}$ BDI (German Industry Association), 'Partner and systemic competitor - How do we deal with China's statecontrolled economy?', Policy Paper, January 2019, p. 13.

${ }^{29}$ Office of the United States Trade Representative, Findings of the investigation into China's acts, policies, and practices related to technology transfer, intellectual property, and innovation under Section 301 of the Trade Act Of 1974, March 22, 2018, p. 148.

${ }^{30} \mathrm{Id}$.

${ }^{31} \mathrm{Id}$.

${ }^{32} I d$., p. 150.

${ }^{33}$ European Commission and High Representative of the Union for Foreign Affairs and Security Policy, Joint Communication to the European Parliament, the European Council and the Council: EU-China - A Strategic Outlook, 12 March 2019, p.1.

${ }^{34}$ China's Position Paper on WTO Reform, Dec. 20, 2018, http://english.mofcom.gov.cn/article/counselorsreport/americaandoceanreport/201812/20181202813857.shtml

${ }^{35}$ World Trade Organization, 'China's proposal on WTO reform', note 2 above, paragraph 2.16.
} 
investment security review', 36 and seeking safeguard for 'legitimate public policy objectives as Internet sovereignty'. ${ }^{37}$

What makes the current situation delicate is not that actors are disputing whether China abides by the 'market-orientation' of international economic law. It is that a challenge is now open over what exactly constitutes 'market-orientation'. As Robert Gilpin argued '[e]ffective and legitimate governance requires agreement on the purpose of the international economy'. ${ }^{38}$ The emerging clash of models suggests that such an agreement might be beyond reach.

Given the difficulty in finding compromises, actors are increasingly standing up to China by also deploying geoeconomic measures, thus triggering a chain reaction whose systemic effects over global regulation will be examined later in this article. In March 2019, the Committee on Foreign Investment in the United States (CFIUS) ordered a Chinese investor to sell its stakes in the gay dating app "Grindr", on account of national security concerns relating to access of the data made available by users of the service. ${ }^{39}$ By the same time, the first ever EU-level mechanism to screen foreign investments was being adopted with the purpose of scrutinizing foreign investments that might affect the 'security or public order'. ${ }^{40}$

Yet, national security is not the only justification for measures being adopted or discussed as possible responses to address the perceived challenges posed by the Chinese economic model. Also in 2019, the European Commission came under heavy criticism by economic authorities in France and Germany when it decided to prohibit the acquisition of the French company Alstom by German manufacturer Siemens, on the grounds of harm to competition. ${ }^{41}$ Unlike their colleagues at the national competition bodies, French and German economy ministers were campaigning for the deal in order to create a 'European champion' in the railway sector that could compete with its Chinese (state-owned) rivals. This would be part of an emerging Franco-German vision for an EU industrial policy premised on the understanding that '[a] strong industry is (...) what will give Europe its economic sovereignty and independence'. ${ }^{42}$

These developments point to increased state action, in the US and Europe, to manage their exposure to interdependence: ${ }^{43}$ they interfere in the economy in order to protect strategic interests, namely retaining domestic technologies (with investment screening) and the capacity of large market players to compete against subsidized foreign companies (such as in the proposal to promote 'European champions').

These geoeconomic measures are reactions to previous geoeconomic measures adopted by China. How does this seemingly self-feeding process starts? To answer this question, the next

\footnotetext{
${ }^{36} I d$., paragraph 2.35 .

${ }^{37} I d$., paragraph 2.22 .

${ }^{38}$ Robert Gilpin, Global Political Economy (Priceton: Princeton Univ. Press), 2001, p. 11.

${ }^{39}$ Carl O'Donnell, Liana B. Baker and Echo Wang, 'Told U.S. security at risk, Chinese firm seeks to sell Grindr dating app', Reuters, March 27, 2019.

${ }^{40}$ Regulation (EU) 2019/452 of the European Parliament and of the Council of 19 March 2019 establishing a framework for the screening of foreign direct investments into the Union, OJ L 79I , 21.3.2019, p. 1-14.

${ }^{41}$ European Commission, 'Mergers: Commission prohibits Siemens' proposed acquisition of Alstom', press release of 6 February 2019.

${ }^{42}$ Bundesministerium für Wirtschaft und Energie and Ministère de l'Economie et des Finances, A FrancoGerman Manifesto for a European industrial policy fit for the 21st Century. See also European Political Strategy Centre, 'EU industrial policy after Siemens-Alstom - Finding a new balance between openness and protection', Brussels, 2019.

${ }^{43}$ Henrique Choer Moraes, 'The turn to managed interdependence: a glimpse into the future of international economic law?’, EJIL Talk!, 14 August 2018.
} 
part of the article examines China's geoeconomic approach to data regulation. This is then followed by an examination, in Part III, of the systemic effects to global regulation that such geoeconomic measure entails. The goal of this analysis is not only to understand how this dynamic unfolds, but hopefully also to contribute to bring to a halt such self-feeding process, which, if anything, undermines the rule of law that now supports international economic law, as discussed below.

\section{DATA LOCALIZATION AS NATIONAL SECURITY: THE GEOECONOMICS OF ARTIFICIAL INTELLIGENCE IN CHINA}

Few elements of modern life epitomize global interdependence as the Internet. The promise of bringing together people from across the world in a marketplace of ideas, above political divides and where economic asymmetries are mitigated, certainly contributed to associate the Internet with the possibility of a better world. ${ }^{44}$ What is witnessed today, though, is that the Internet will remain a borderless space only in so far as the sovereigns decide to leave it so. ${ }^{45}$ With growing state intervention on the cyberspace, as well as abusive practices by large tech companies, the current Internet landscape has come to increasingly resemble what commentators describe as the 'splinternet'. ${ }^{46}$

An eloquent expression of the present threat of fragmentation of the Internet are national legislations requiring so-called 'data localization' or restricting cross-border data flows-a regulatory area whose importance reveals that the digital economy has evolved beyond the realm of electronic commerce of goods and services to also cover data.

This part looks at the Chinese regulation of data, which is an element of its national security legislation. By restricting access to data, China might be pursuing objectives more directly related to the Chinese regime's concerns. Nevertheless, it is argued that data regulation in China is also an instrument to spur its development of artificial intelligence. The claim articulated in this part is that the resort to national security to promote local mastery of a crucial set of technologies is a geoeconomic measure.

\section{A. Data as a strategic asset in the global economy}

The global expansion of the Internet, helped by the wide dissemination of mobile devices equipped with significant computing power such as smartphones, ushered in the data-driven economy we currently live in: in 2017 , there were 3.77 billion people accessing the Internet, 2.8 billion of which are active on social media as well as 4.92 mobile users, as documented by the Digital in 2017 Global Overview report. ${ }^{47}$ While Facebook reported in 2018 that 2.5 billion

\footnotetext{
${ }^{44}$ John Perry Barlow, 'A Declaration of the Independence of Cyberspace', delivered at Davos, February 8, 1996, available at https://www.eff.org/cyberspace-independence.

${ }^{45}$ Eric Schmidt and Jarred Cohen, The New Digital Age: Reshaping the Future of People, Nations and Businesses, Alfred Knopf, 2013, p. 83.

${ }^{46}$ Scott Malcomson, Splinternet: How Geopolitics and Commerce are Fragmenting the World Wide Web (New York: OR Books), 2016; Matthew Bey, 'The Age of Splinternet: The Inevitable Fracturing of the Internet', Stratfor, April 25, 2019.

${ }^{47}$ Digital in 2017 Global Overview, available at https://wearesocial.com/special-reports/digital-in-2017-globaloverview.
} 
people use any of its family of apps each month, ${ }^{48}$ the Chinese all-encompassing mobile phone app WeChat reached 1 billion users in 2018. ${ }^{49}$

This massive migration of social activity to the online world leaves a significant footprint in the form of data. As a result, the amount of data created in the world is expected to increase enormously. The International Data Corporation forecasts that by 2025 'the global datasphere will grow to 163 zettabytes (that is a trillion gigabytes). That's ten times the 16.1ZB of data generated in 2016'. ${ }^{50}$ This trend will only accelerate with the advent of the 'Internet of Things', in which devices as ordinary as refrigerators become connected with each other and generate data themselves.

In the not so distant past, data used to be discarded shortly after creation due to the high costs associated with their keeping. Yet, over the years data storage has grown increasingly affordable - and this has, in turn, led to the emergence of two crucial elements enabling the data-driven economy, namely 'big data' and 'cloud computing'.

'Big data' is a source of formidable disruptive potential thanks to the development of technologies that help make sense of vast troves of data. One of the most promising uses of big data lies in the development of artificial intelligence, an area that requires massive volumes of computer power and data. While 'data 'trains' the program to recognize patterns by giving it many examples, (...) the computing power lets the program parse those examples at high speeds'. ${ }^{51}$ Big data is enabled because data previously dispensed with can now be kept in large data centers that offer storage space for a fraction users would pay if they needed to bear all the costs with storage. This is 'cloud computing', an 'umbrella term for the Internet-based technologies through which data are processed and stored across multiple servers to be accessed over the Internet on demand'. 52

Because it shifts the handling and management of data from users to cloud providers, the consolidation of cloud computing catalyzed the concern with the protection of data online. This concern was compounded by the 2013 Edward Snowden revelations of massive scale spying by the US government, which led many countries to question the wisdom of relying on a strictly technical design of the cloud infrastructure, including the physical location of data storage. The Snowden episode accounted for an upsurge in so-called 'data localization' requirements in domestic legislations in different parts of the world. ${ }^{53}$ The 2018 Digital Trade Restrictiveness Index of the European Centre for International Political Economy recorded 84 data localization requirements imposed by 64 economies across both the developed and developing world. ${ }^{54}$

Rather than allowing cloud service providers the liberty to choose the location in the world to store data following cost-effectiveness considerations, data localization measures 'either

\footnotetext{
${ }^{48}$ Michelle Castillo, 'Facebook plunges more than 24 percent on revenue miss and projected slowdown', $C N B C$ Markets, July 25, 2018.

${ }^{49}$ Rayna Hollander, 'WeChat has hit 1 billion monthly active users', UK Business Insider, March 6, 2018.

${ }^{50}$ Id., p. 3.

${ }^{51}$ Kai-Fu Lee, AI Superpowers: China, Silicon Valley, And The New World Order (Boston: Houghton Mifflin Harcourt), 2018, location 202 (kindle edition).

${ }^{52}$ United States International Trade Commission, Global Digital Trade 1: Market Opportunities And Key Foreign Trade Restrictions, 2017, p. 58.

${ }^{53}$ Anupam Chander and Uyên P. Lê, 'Data nationalism', 64 Emory Law Journal 679 (2015). See also Gordon M. Goldstein, 'The end of the Internet? How regional networks may replace the World Wide Web', The Atlantic, 24 July/August 2014.

${ }^{54}$ European Centre for International Political Economy, Digital Trade Restrictiveness Index, 2018, p. 55
} 
mandate data to be kept locally or impose conditions to transfer data cross-border'. ${ }^{55}$ These measures can be more or less constraining, ranging from the outright ban of data transfer outside a given state to the requirement that data be processed within the territory before crossing borders. Either way, given the additional costs imposed by compliance with these measures, analysts consider that data localization requirements represent barriers preventing companies from resorting to cloud computing, despite the economy this service generates. ${ }^{56}$

As the fallout from the Snowden disclosures suggest, data localization and restrictions on data flows have often been imposed on grounds of privacy protection and as defense against foreign surveillance, or national security more broadly. Analysts also identify cases of data localization whose inspiration would come from what has been dubbed 'economic mercantilism', ${ }^{57}$ which essentially means forcing localization as a way to induce economic activity and job creation in a given state.

Critics dismiss data localization as a counterproductive remedy to address any of these concerns. It is argued that these measures do nothing to make data safer ${ }^{58}$ since, for example, 'localized data servers reduce the opportunity to distribute information across multiple servers in different locations'. ${ }^{59}$ Data localization requirements would furthermore entail costs for the states imposing them, since 'any job gains as a result of data localisation are minuscule compared to losses in terms of jobs and output in other parts of the economy'. ${ }^{60}$

As examined below, China imposes data localization requirements on certain categories of information on national security grounds. While the Chinese policy might be challenged by the above criticisms, it also represents a unique case of a geoeconomic use of data localization: by limiting the cross-border flow of data from its territory, China retains control over a valuable asset in its strategy of technological catch up by becoming a leader in artificial intelligence.

\section{B. Data regulation and the Chinese strategy on artificial intelligence}

Given the potentially transformative effects of artificial intelligence, Russian President Vladimir Putin famously declared that 'whoever masters it first will rule the world'. ${ }^{61}$ Data is a key input in the development of AI and China is leveraging the significant amount of data it generates to boost its position as an AI leader.

The unique size of the online population in conjunction with the pervasive presence of mobile platforms makes China an outstanding source of data. In 2018, China boasted 802 million Internet users (57.7\% of the population), $98 \%$ of which are mobile users. ${ }^{62}$ In comparison, data

\footnotetext{
${ }^{55}$ Id., p. 98.

${ }^{56}$ W Kuan Hon, Data Localization Laws And Policy - The EU Data Protection International Transfers Restriction Through A Cloud Computing Lens, London: Edward Elgar, 2017, p. xii.

${ }^{57}$ Nigel Cory, 'Cross-border data flows: where are the barriers, and what do they cost?', Information Technology and Innovation Foundation, May 2017, p. 5.

${ }^{58}$ Patrick Ryan, Sarah Falvey and Ronak Merchant, 'When the cloud goes local: The global problem with data localization', 46 Computer 12 (2013), p. 57.

${ }^{59}$ Anupam Chander and Uyên P. Lê, 'Data nationalism', n. 88 above, p. 719.

${ }^{60}$ Matthias Bauer, Hosuk Lee-Makiyama, Erik van der Marel and Bert Verschelde, 'The costs of data localisation: Friendly fire on economic recovery', ECIPE Occasional Paper No. 3, 2014, p. 3.

61 'Whoever leads in AI will rule the world': Putin to Russian children on Knowledge Day', RT, 1st September, 2017, available at https://www.rt.com/news/401731-ai-rule-world-putin/.

${ }^{62}$ Niall McCarthy, 'China now boasts more than 800 Million Internet users and $98 \%$ of them are mobile', Forbes, August 23, 2018.
} 
from 2017 and 2018 showed that the US had 286 million Internet users (88\% of the population) ${ }^{63}$ while the European Union had 460 million (90\% of the population). ${ }^{64}$

China takes an approach to data flows and data localization that differs from that adopted by some Western countries. A recent OECD conference on AI urged 'the need for enhanced access to data to leverage AI broadly, through open data policies, data interoperability and data format standardisation as well as better management of personal data'. The views expressed at that occasion point to the perception that open access to data is crucial to drive AI research, at least for the OECD countries. ${ }^{65}$

In contrast, data localization measures implemented by China embrace a different rationale, one in which the outflow of some types of data are subject to control, if not to outright ban. These measures are part of the Cybersecurity Law, which 'is formulated in order to: ensure cybersecurity; safeguard cyberspace sovereignty and national security, and social and public interests' (Article 1). ${ }^{66}$ Data localization and data flow restrictions are thus tools in the defense of China's national security.

This stance is part of the Chinese approach to Internet governance, which is a projection to the digital sphere of the notion of sovereignty. For China, 'the principle of sovereignty enshrined in the UN Charter covers all aspects of state-to-state relations, which also includes cyberspace'. 67

Data localization is specifically set out in Article 37 of the Chinese Cybersecurity law, but using broad language: '[c]ritical information infrastructure operators that gather or produce personal information or important data during operations within the mainland territory of the People's Republic of China, shall store it within mainland China'.

The implementing legislation of the Cybersecurity Law does not dispel the ambiguity, as can be seen in the definition of 'important data', a category of data that should be stored in China: 'Important data refers to data closely related to national security, economic development, and social public interest' (Article 17). The definition of 'critical information infrastructure' is another key concept whose contours are unclear. ${ }^{68}$

As a result of the broadly-worded legislation, American companies in China currently operate on the assumption that 'data localization requirements will become the de facto reality for their China operations'. Likewise, 'some Chinese companies have already stopped sending their data to foreign companies that had the ability to store and process data within mainland China'. ${ }^{69}$

\footnotetext{
${ }^{63} 2018$ Digital Yearbook, available at https://www.slideshare.net/wearesocial/2018-digital-yearbook-86862930.

${ }^{64}$ See Internet World Stats, available at https://www.internetworldstats.com/europa.htm.

${ }^{65}$ Organization for Economic Cooperation and Development, AI: Intelligent Machines, Smart Policies. Conference Summary, OECD Digital Economy Papers, 2018, No. 270, p.6.

${ }^{66}$ The Cybersecurity Law is in effect since June $1^{\text {st }}, 2017$. For an unofficial English translation, see https://www.newamerica.org/cybersecurity-initiative/digichina/blog/translation-cybersecurity-law-peoplesrepublic-china/.

${ }^{67}$ International strategy of cooperation on cyberspace, China Daily USA, March 2, 2017.

${ }^{68}$ Samm Sacks and Manyi Kathy Li, 'How Chinese Cybersecurity Standards Impact Doing Business in China', CSIS briefs, August 2018.

${ }^{69}$ Samm Sacks, 'Addressing China's Technology Policies: Beyond the Whiplash of a ZTE Deal', Lawfare, May $25,2018$.
} 
Some critics argue that, despite being adopted for national security considerations, these measures give expression to 'digital protectionism to carve out a privileged space for Chinese firms'. ${ }^{70}$ While this might be a reasonable claim, data localization and data flows restrictions seem also bent on attaining broader, strategic goals that go beyond the interest of possible national champions. As articulated below, among these goals is the geoeconomic strategy of fostering the development of AI. ${ }^{71}$

National strategies adopted by China offer elements to substantiate the link between the provisions on data localization and data flow restrictions and the development of AI. ${ }^{72}$ One of them is the 'Big Data strategy', addressed in the $13^{\text {th }}$ Five-Year Plan (2016-2020), in which big data is considered a 'fundamental strategic resource'. ${ }^{73}$

Following up on the $13^{\text {th }}$ Five-Year Plan, the State Council's 2015 Action Plan for Promoting Big Data Development pledges to make full use of China's 'data scale advantage'. It acknowledges that 'big data has become an important basic strategic resource of the country and is leading a new round of technological innovation'. The Action Plan highlights that achieving data scale 'is conducive to better play the strategic role of data resources, enhance the sovereign protection of cyberspace data, and safeguard national security.' 74

The importance of channeling the vast pool of data produced in China to the effort of securing a leading position on AI is also present in the State Council Notice on the Issuance of the Next Generation Artificial Intelligence Development Plan. Chinese authorities state that 'AI is a strategic technology that will lead in the future; the world's major developed countries are taking the development of AI as a major strategy to enhance national competitiveness and protect national security'. ${ }^{75}$

Some of the actions comprised in this strategy acknowledge the vast data pool as 'China's unique advantage in AI development'. Therefore, the Plan calls for coordination in the 'use of big data infrastructure (...) to provide massive data support for AI research and development and extensive applications. ${ }^{, 76}$

Interestingly, while outflows of data from China are subject to restrictions such as data localization measures, researchers working with AI in China point to ease of access to data as

\footnotetext{
${ }^{70}$ Council on Foreign Relations, 'The rise of digital protectionism - Insights from a CFR workshop', 2017.

${ }^{71}$ Anthea Roberts, Henrique Choer Moraes and Victor Ferguson, 'Geoeconomics: the Chinese Strategy of Technological Advancement and Cybersecurity', Lawfare, December 3, 2018; Alan Beattie, 'Data protectionism: the growing menace to global business', Financial Times, May 13, 2018; Martina Ferracane and Hosuk Lee-Makyiama, 'China's technology protectionism and its non-negotiable rationales', European Center for International Political Economy, June 2017, available at http://ecipe.org/publications/chinas-technologyprotectionism; Jeffrey Ding, 'Deciphering China's AI Dream - The context, components, capabilities, and consequences of China's strategy to lead the world in AI', Future of Humanity Institute/University of Oxford, 2018 , p. 25.

${ }^{72}$ Yanqing Hong, 'The cross border data flows (data exit) security assessment: an important part of protecting China's basic strategic resources', 2018, available at http://www.dgcs-research.net/a/Opinion/2018/0103/59.html

73 'We will make big data a fundamental strategic resource and fully implement a plan for its development, accelerating the opening, sharing, development, and application of data resources so as to help transform and upgrade industries and bring about innovations in social governance.' (The 13th Five-Year Plan For Economic And Social Development Of The People's Republic Of China (2016-2020), Chapter 27 - Implement the National Big Data Strategy).

${ }^{74}$ China State Council, Action Plan for Promoting Big Data Development, 2015, http://www.gov.cn/zhengce/content/2015-09/05/content_10137.htm

${ }^{75}$ Unofficial translation available at https://www.newamerica.org/documents/1959/translation-fulltext-8.1.17.pdf ${ }^{76} \mathrm{Id}$.
} 
one of the reasons for carrying out their projects there. According to reports '[1] eaders in the AI field continue to cite ease of data access in China as a major selling point' ${ }^{77}$; ' $[\mathrm{t}]$ he field is booming in China, in large part because researchers have access to patient data that would be off-limits in other countries ${ }^{78}$; and '[a] lot of foreign scientists want to apply to work in China because of the [availability of] data.' 79

Data outflow is inhibited, among other reasons, because it is a key input in the development of a crucial technology - in this sense, data is not so different from rare earths. But domestic circulation of data is facilitated for researchers advancing the AI technology in China, a national security goal.

This narrative gains more sense when one examines the current stage in the global development of AI. In the view of Kai Fu-Lee, a leading venture capitalist and a pioneer in AI research funding in China, the state of the art is marked by incremental improvements on the latest AI technological breakthrough, called 'deep learning'. In his view, no groundbreaking innovations should be expected in the short term. Instead, the current stage in AI research calls for refining the algorithms designed by elite researchers - mainly from and in the US - and to put them to economic use. We have moved from the 'age of discovery' to the 'age of implementation', according to Lee: 'Today, successful AI algorithms need three things: big data, computing power, and the work of strong-but not necessarily elite-AI algorithm engineers. Bringing the power of deep learning to bear on new problems requires all three, but in this age of implementation, data is the core.' 80

According to Lee, China is particularly suited to win the 'age of implementation' given the massive amount of data its hyper-connected population generates. China's advantage lies not only in the volume of data it produces (something that, for instance, Facebook has at its disposal), but also in the granularity of this data, which results from the fact that the Chinese use the Internet for an exceedingly higher number of actions than non-Chinese users. ${ }^{81}$

Lee's understanding on the current stage of AI development might be debatable, ${ }^{82}$ but it nevertheless provides a narrative that helps place China's policies regarding data within a broader strategy - and data regulation is part of it. It is a geoeconomic strategy, in which the state deploys economic regulation over access to data-adopted as a national security measure - to retain within China's jurisdiction the control over a key input in the development of artificial intelligence.

Thus, by retaining data in China with localization and data flow restrictions, a crucial input is preserved for the development of AI and thereby for the pursuit of a goal that is of national security. In this sense, data localization in China does not seem to be motivated exclusively by those reasons for which it is often criticized: protection against foreign surveillance, privacy or even 'digital protectionism'. It might be inspired by these goals, but there is also a broader

\footnotetext{
${ }^{77}$ Owen Churchill, 'China's AI dreams', Nature, January 17, 2018, available at https://www.nature.com/articles/d41586-018-00539-y

${ }^{78}$ Henny Sander, 'China's great leap forward in biotech - Access to vast amounts of patient data fuels innovation

-- and controversy', Nikkei Asian Review, October 3, 2018.

${ }^{79}$ Christina Larson, 'China's massive investment in artificial intelligence has an insidious downside', Science, February 8, 2018.

${ }^{80}$ Kai-Fu Lee, AI Superpowers: China, Silicon Valley, And The New World Order, 2018, n. 16 above, locations 283-284 (Kindle edition).

${ }^{81}$ Id., location 951.

${ }^{82}$ Rana Foroohar, 'Advantage China in the race to control AI?’, Financial Times, September 21, 2018.
} 
objective behind it. The logic underlying the domestic legal framework in China has spill-over effects over international economic law, as detailed in the next part.

\section{THE GEOECONOMIC CHALLENGE AND THE EVOLUTION OF INTERNATIONAL ECONOMIC LAW}

Already in 1998 John Jackson noticed that the reinvigoration of international trade law was taking place in tandem with what he described as a shift to geoeconomics, and he cautioned against a 'politicization of international economic policy issues'. ${ }^{83}$ His fears were dispelled in the following years, particularly because the economic and security agendas evolved by and large in separate tracks, with little convergence barring the exceptional, and economically negligible, cases of economic sanctions. ${ }^{84}$

The emerging clash of models brings back the prospect of 'politicization' of international economic law. This part argues that this is a phenomenon already taking shape and the regulation of data provides examples of what it means concretely to 'politicize' international economic law.

From a structural angle, the clash of models might usher in an even a more 'selective multilateralism' in view of the increasingly irreconcilable differences between the major actors, which renders multilateral agreement more difficult. As a result of these difficulties to advance at the international level, the space for domestic economic regulation tends to expand. Domestic-level lawmaking is also likely to become more frequent in view of the interest to 'manage the interdependence' vis-à-vis other models, as China does when it restricts data flows. Finally, major actors are also likely to seek to disseminate their models in what might become 'spheres of influence', i.e., spaces where legal regimes structured around one of the models can thrive.

\section{A. The intensification of 'selective multilateralism'}

The differences that set the Chinese view on data regulation apart from the position of a free Internet go beyond the divergence of interests. They represent a manifestation of the clash of models. It is true that data regulation stands at the intersection of Internet governance and international economic law. ${ }^{85}$ But, as shown above, in China it also plays a role in advancing the interest in developing leadership in AI. What is more, this interest is couched in national security terms in China. This begs the question: what international rules, if any, discipline the trade effects of China's data localization and data flow restrictive measures?

Multilateral discussions on data regulation have only recently started at the WTO. ${ }^{86}$ Still, they already display a dynamic that is relevant to understand how the clash of models plays out in the realm of international economic law: countries that favor the free flow of data, such as the

\footnotetext{
${ }^{83}$ John Jackson, 'Global economics and international economic law', 1 Journal of International Economic Law (1998), p. 11.

${ }^{84}$ Anthea Roberts, Henrique Choer Moraes and Victor Ferguson, 'Geoeconomics: The Variable Relationship Between Economics and Security’, Lawfare, November 27, 2018.

${ }^{85}$ John Selby, 'Data localization laws: trade barriers or legitimate responses to cybersecurity risks, or both?', 25 International Journal of Law and Information Technology 232 (2017) .

${ }^{86}$ See Ines Willemyns, 'The GATS (in)consistency of barriers to digital services trade', Leuven Centre for Global Governance Studies Working Paper No. 207, September 2018; Chris Mirasola, 'U.S. Criticism of China's Cybersecurity Law and the Nexus of Data Privacy and Trade Law', Lawfare, October 10, 2017; Chris Mirasola, 'An update on Chinese cybersecurity and the WTO', Lawfare, March 2, 2018.
} 
US and Japan, claim that multilateral rules constrain China's policy space. Conversely, China contends that it enjoys freedom to discipline this topic without limitation from international rules.

In the WTO Council for Trade in Services (GATS Council), for instance, the US is arguing that the Chinese Cybersecurity Law was inconsistent with the GATS Agreement. Regarding data localization measures in particular, the US claims their impact 'would fall disproportionately on foreign service suppliers operating in China'. ${ }^{87}$ Japan took a similar position, complaining that Chinese data localization measures 'could place foreign network operators in a less competitive situation than the local operators'. ${ }^{88}$

China, for its part, has traditionally restrained itself from advancing an ambitious international agenda on digital trade topics such as data localization and cross-border data flows. ${ }^{89}$ At the WTO debates, it has by and large claimed that 'Members had the right to design regulatory measures in line with their specific conditions, and needed to protect their people's interests and public policy objectives'. ${ }^{90}$ On some occasions, though, it argued for a link between data flow restrictions and 'national cybersecurity'. ${ }^{91}$ More recently, in the framework of the negotiations on electronic commerce, China stated that 'data flow[s] should be subject to the precondition of security, which concerns each and every Member's core interests'. 92

It is noteworthy that China falls short of expressly articulating its defense on the national security exceptions allowed by the GATS Agreement, set out by Articles XIV and XIVbis. It also remains to be seen whether other WTO Members would genuinely have an interest in taking this discussion to a formal dispute or whether lack of clarity regarding the exact reach of the GATS rules would be politically more suitable.

Irrespective of the position on the legality of China's data localization measures vis-à-vis international rules, what is relevant to observe is the tug-of-war whereby, depending on their interests, parties make their claims either in favor of international disciplines or of domestic discretion to regulate. The multilateral debate on data localization and data flows reveals that, in questions where models collide, there is a fundamental difficulty in bringing together the competing positions. This suggests that in areas deemed strategic for key players the route might be blocked for multilateral lawmaking, which will become even more 'selective' than it already is. What makes this situation even more serious is that, in a context of management of interdependence, the number of areas considered strategic-or considered of national security-tends to increase.

Lack of conditions to advance lawmaking at the multilateral level—particularly on issue-areas considered strategic or of 'national security' - push regulation to the domestic level, with the

\footnotetext{
${ }^{87}$ World Trade Organization, 'Communication from the United States - Measures adopted and under development by China relating to its cybersecurity law', document S/C/W/374, September 26, 2017.

${ }^{88}$ World Trade Organization, 'Council for Trade in Services, Report of the meeting held on 6 October 2017 - Note by the Secretariat', document S/C/M/133, November 6, 2017, paragraph 6.6.

${ }^{89}$ Henry Gao, 'Digital or trade? The contrasting approaches of China and the US to digital trade', 21 Journal of International Economic Law (2018), p. 310-312.

${ }^{90}$ World Trade Organization, 'Council for Trade in Services, Report of the meeting held on 30 May 2018 - Note by the Secretariat', document S/C/M/135, July 11, 2018, paragraph 7.11.

${ }^{91}$ World Trade Organization, 'Council for Trade in Services, Report of the meeting held on 6 October 2017 Note by the Secretariat', document S/C/M/133, November 6, 2017, paragraph 6.59

${ }^{92}$ World Trade Organization, 'Joint statement on electronic commerce - Communication from China', document INF/ECOM/19, 24 April 2019.
} 
possibility of also translating into disputes to extend influence over third markets. Both these developments are addressed in the following sections.

\section{B. De-legalization and de-internationalization: expansion of domestic-level regulation}

The case of data localization in China brings to light a number of features that might be relevant to understand not only the prospects for multilateral rules in this area, but also in other sectors considered strategic.

First, it suggests a resistance by China to move regulation of data localization to the international level (whether there already exists GATS rules disciplining this topic is a different matter that does not need occupy us here). The preference expressed by China is to keep regulation of this issue at the domestic level, while at the same time the US and Japan lead the group that pushes for multilateral treatment.

China couches its position as a national cybersecurity issue, which reveals an expansion of the scope of what might traditionally be considered under 'national security'. At the same time, this claim does not seem entirely deprived of legitimacy. What is symptomatic about the invocation of national security in this case is precisely that it is difficult to label it as outright abusive. This in turn suggests that the range of areas considered strategic or security-sensitive is in a state of flux, something that points to the geoeconomic influence over the interpretation of international economic law.

Another relevant take-away from the data regulation case in China is that, at the domestic level, the disciplines are marked by a lack of precision in key terms such as 'critical information infrastructure' and 'important data'. ${ }^{93}$ This feature that translates into more discretion to local authorities, which can calibrate the scope of these rules at will. ${ }^{94}$

Interestingly, the leeway enjoyed by the Chinese authorities due to the imprecise wording of the legislation points to an apparent paradox regarding the prospect of China subscribing multilateral rules in this area: since data localization is considered a 'national security' issue, it seems difficult to expect China to endorse international disciplines, as national security concerns are not subject to negotiation. At the same time, given the flexibility the Chinese authorities enjoy to interpret the domestic rules, they can calibrate what exactly is covered by national security - and, therefore, agree on international rules if they consider appropriate.

All in all, this suggests a transactional approach to regulation in this area which impacts the quality of the rule of law, in particular inviting criticisms from market operators, whose businesses are affected by the lack of predictability emerging from this uncertainty. ${ }^{95}$

\section{The emergence of spheres of legal influence}

The state of play of the WTO debates on data localization suggests a possible pattern in the legal treatment of topics that are considered crucial for one major economic power. That case

\footnotetext{
${ }^{93}$ United States Trade Representative, 2018 Report to Congress On China's WTO Compliance, Feb. 2019, p. 158.

${ }^{94}$ Graham Webster, Samm Sacks and Paul Triolo, 'Three Chinese Digital Economy Policies at Stake in the U.S.-China Talks', DigiChina - New America, 2 April, 2019.

${ }^{95}$ Lee, Jyh-An, Hacking into China's Cybersecurity Law, The Chinese University of Hong Kong Faculty of Law Research Paper No. 2018-08, p. 61-62.
} 
suggests it will be difficult to agree on multilateral rules on this topic given the seemingly irreconcilable views between the US and China. Lack of agreement already has concrete impact on the evolution of the digital economy, as companies wanting to operate in China need to adapt to the local rules - and many are doing just that. ${ }^{96}$

In the absence of multilateral agreement on new rules of the game, we should expect actors such as China, the US and the EU to develop their own approaches at the domestic level and to seek to export those approaches to likeminded or dependent states and regions. ${ }^{97}$ This fragmented picture is already a reality in data regulation. A recent survey by the RAND Corporation, for example, concluded that '[i]ndividual national regulations governing data transfer and privacy will not significantly converge in the foreseeable future.' 98

More specifically, three spheres of legal influence —or 'data realms' 99 —are emerging, expressing different approaches to the regulation of data localization and data flows.

The first is a US-based one, reliant on the free flow of data, light-touch privacy regulation and on a ban to data localization and discouraging restrictions on free data flow. The US has been spreading its regulatory preferences by means of, among others, free trade agreements (FTAs) such as the recent USMCA. US FTAs provisions against restrictions on cross-border data flows and data localization seek to expand the data pool from which its companies can develop better AI technologies. ${ }^{100}$ This way, US businesses can tap into a larger reservoir of data than would be possible if they were confined to simply the US population. It can in fact be legitimately claimed that negotiating commitments to ensure the free cross-border data flow is the US geoeconomic approach to data flows.

The second sphere of influence is that promoted by the EU, which is heavily focused on protecting privacy over personal data and, therefore, is strict on allowing data flows only under certain circumstances. The EU approach revolves around its domestic legislation, the General Data Protection Regulation - GDPR, in force since 2018. Until the entry into force of the GDPR, the EU has been disseminating its approach by means of "adequacy decisions" whereby the European authorities assess whether the level of data protection in third countries satisfies that applied in the EU. Most recently, the EU has signed its first "adequacy agreement" on this area, with Japan, by which the parties agreed on standards to be applied in the treatment of personal data regarding EU nationals.

The third sphere is spearheaded by the Chinese, which is marked, as seen above, by an enclosure system motivated by national security concerns as well as other public policy goals, such as possibly the state surveillance of individuals. One way of expansion of the Chinese cybersphere would be under the Belt and Road initiative, particularly its digital extension, the 'Digital Silk Road'. But China is also showing leadership in disseminating its approaches to Internet

\footnotetext{
${ }^{96}$ Josh Horwitz, 'A key question is at the heart of China's new cybersecurity law: Where should data live?', Quartz, June 7, 2017.

${ }^{97}$ On the mechanisms through which domestic interests drive great power's goals in the design of international regulatory regimes, see Daniel W. Drezner, All Politics Is Global: Explaining International Regulatory Regimes (New Jersey: Princeton University Press, 2009).

${ }^{98}$ Marlon Graf, Jakub P. Hlavka, Bonnie L. Triezenberg, 'Strong Winds Ahead for Cloud Computing: Can Data Localization Threaten Future Growth?’, The RAND Blog, April 29, 2016.

${ }^{99}$ Susan A. Aaronson and Patrick Leblond, note 14 above.

100 Susan Ariel Aaronson, 'Data minefield? How AI is prodding governments to rethink trade in data', Data Governance in the digital age, Center for International Governance Innovation, 2018, p. 117.
} 
governance and cyber security more broadly. ${ }^{101}$ Since 2014, the Chinese government has been promoting the annual World Internet Conference (Wuzhen Summit) attended by guests from across the world, both governmental and non-governmental. ${ }^{102}$

Initiatives such as the ones above suggest an interesting feature of the Chinese cyber-sphere of influence. While China shows aversion to joining the interdependent infrastructure and network underpinning the Internet-by decoupling measures such as data localization-it feels comfortable in promoting its own network of interdependence with states willing to do so. This can also involve accessing data from those other states. For instance, it has been reported that a Chinese artificial intelligence company has been providing surveillance mechanisms to Zimbabwe in a deal that, in exchange, will grant it access to data 'on millions of black faces ... to help train the [company's] technology toward darker skin tones. ${ }^{\prime} 03$

These three spheres are only emerging and it remains unclear whether-or to which extentany degree of convergence among them is possible. What is relevant to note, though, is that they offer different views on the regulation of a key pillar of the digital economy, an arena where the US and China want to lead, and where the EU seeks to stand its ground. The way these actors behave going forward will define the evolution of the digital economy and, by consequence, of international economic law.

\section{CONCLUDING REMARKS}

This article argued that a clash of economic models is gaining pace in the wake of China's globally expanding economic presence. This clash is characterized by an increasingly open criticism of China's 'geoeconomic' methods, which are seen as contradictory to the letter and spirit of international economic law. Equally important, the emergence of such clash is evidence of the inability of actors such as the US, the EU and Japan to persuade China to change course. Given this tension, the former are confronted with the challenge of managing the increasing competition from China, especially in each of their domestic markets but gradually also in third markets. And they are doing so by deploying geoeconomic measures targeting China, thereby triggering a geoeconomic chain reaction.

A second claim of the article is that this geoeconomic dynamic alters the logic that has inspired international economic law, particularly the interest in curbing economic nationalism, harnessing the positive aspects of interdependence and increasing the rule of law in economic relations. In order to spell out how geoeconomics plays out in practice, as well as its consequences for global regulation, the article examined the regulation of data in China, as well as the current status of regulation of data flows at the international level.

The case study of data localization in China suggests a number of possible implications for the future of international economic law in this and possibly in other areas considered strategic for other actors. Among these implications, we might expect regulation to be less international (but more domestic), less legalized (instead, more subject to the discretion of national authorities) and less multilateral (but more situated under spheres of influence). These implications could

\footnotetext{
101 Valentin Weber, 'Why China's Internet Censorship Model Will Prevail Over Russia's', Council on Foreign Relations, 12 December 2017. On China's model generally, see Adam Segal, 'When China Rules the Web', Foreign Affairs, September/October (2018).

102 'China to hold 5th World Internet Conference in November', China Daily, 28 September 2018.

${ }^{103}$ Amy Hawkins, 'Beijing’s Big Brother Tech Needs African Faces', Foreign Policy, 24 July 2018.
} 
be expanded to other issue-areas not addressed in this article, such as the US investment screening mechanism.

International economic lawyers need to understand the shift in the logic underlying global economic relations. This is relevant not only to make sense of how the field is being transformed, but also to hopefully preserve as much as possible the acquis of international economic law, which has been responsible for supporting the significant expansion in economic activity at the global level in the past decades. 